\title{
Discussing on Relationship between Freedom and Authority --- Comments on the History of Liberalism
}

\author{
and John Stuart Mill's $<<$ On Liberty $>>$
}

\author{
Jianzhong Dai \\ Shandong University of Technology \\ Zibo 255049, Shandong, China \\ E-mail: daijian916916@163.com
}

\begin{abstract}
The relationship between freedom and authority is an eternal theme discussing in the meaning of political philosophy. As early as in ancient Greek and Roman period the thinkers begin to discuss this issue precisely. Authority is a kind of invasion to freedom and the freedom also is an inevitable erosion to authority. There are contradictions between freedom and authority and at the same meaning they are mutually compatible. The relationship between freedom and authority constitute a history of liberalism. This article, discusses the relationship between freedom and authority historically, analysis Mill's contribution to liberalism, explore the limitations of the liberal idea of Mill and Green, amended the liberal scheme comprehensively.
\end{abstract}

Keywords: Authority, Liberalism, Freedom

As a sociological sense, the concept of freedom and authority, has a broad interpretation. It can refer to political freedom and political authority, but also refers to economic freedom and economic authority, and also refers to the legal freedom and legal authority, at the same time it refers to religious freedom and religious authority. There are different interpretations on the meaning of freedom and the authority. The focus of this paper is not under the authority and freedom of a precise definition, but in light of the history of liberal freedom and authority .It mainly discusses the relationship between freedom and authority.

Freedom and authority are mutually antagonistic, and at a certain sense they are mutually compatible. Authority is a kind of invasion to freedom and the freedom also is an inevitable erosion to authority. Of course this reason can be reconciled. Freedom is not to eliminate the authority as a fundamental starting point and destination, and the authority is not put an end to the ultimate objective of freedom. To this end, this article is based on the following two default arguments: first, the existence of a free society and authority. Second, human nature is good.

The relationship between freedom and authority constitute a history of liberalism. The subject of liberalism has not been torn off from ancient Greek and Roman to modern times. There was a British philosopher, in his knowledge of strict logic, once pointed out the relationship between freedom and authority which issues on a comprehensive and profound performance, became an modern liberalist during the transition period and make a significant contribution to the figures. This person, "discussed civil liberties or social freedom, explore the legal community, indicated individual nature and limits of power, describe his liberal thinking". This man is John •Stuart •Mill.

The debating on the relationship between freedom and authority has already begun as early as in ancient Greek and Roman period. At that time, Plato, Socrates, Aristotle, etc. have stated the system of slavery based on the freedom evaluation. At the same time, they studied the ethical authority and the political role of freedom. Thinkers, in this period, main pursued the objectives : the city power must be restricted necessarily. And this restriction could render so-called freedom.

First, to strive for the rulers of certain privileges that the recognition of certain political powers is definite. These rights, such as the violations of the rulers, abandoned the obligations, stimulate the individual to resist and rebel can be described as legitimate; Second, it is necessary to establish in law a number of constraints and certain important 
measures must be consistent. It is not difficult to analyze that the ancient Greek and Rome during the main feature of freedom is consist of a recognized group. The authority of the restriction of freedom is an erosion to authority. It is clear that the relationship between freedom and authority always be explained an intercourse of rationality.

Of freedom there have been a lot of serious thinkers to explore. If we do not soon forget the history of the Soviet Union, we must also remember that the Soviet Union Solanesol philosopher Richard Rorty has written a book called "On Liberty". There have great similarities in terms of writing style, but the Mill "On freedom" is quite different in paraphrasing. The book discusses the fact that the system of ancient Greek and Roman have a great similarities with Marxist theory .It is a history of philosophical works. Seeing through the core of the book is relationship between free and authority. The question of the relationship, of course, we should not forget .More than other British social philosopher, Hobhouse, a liberal thinker, famed for the materialism, entitled in "liberalism". In the book, he systematically expounds the theory of liberalism. Reading this book is no doubt an interesting things and it will help us to better grasp the idea of Mill. Among the most exciting part "Chapter VII" we know the "national and personal," the chapter is focused on the relationship between freedom and authority issues. In this regard, Hall House highlighted the following three points: First, freedom is not really enforced the inevitable contradictions and the final analysis is a mutual need. The purpose to force the internal development and well-being is to create the most favorable external conditions. The field of freedom is the growth and development of authority. Between freedom and control of real opposition is a corresponding control. Second, the individual owes the community of social. He pointed out that, individuals less than society in general should know the modern conditions, a person more easily to do as a matter of politics, and given him the state personal safety and freedom of speech as a favorable conditions, starting from this premise, he can not hesitate to scold the behavior of countries, denying the authority of the country. He feels that he is willing to join the social system, not unwilling to join to cooperation. Given to reliance on the protection of the common law he away finds the legal oppression of his conscience. He forgets, or refuses to think about the trouble, if everyone is like him, society will stop the machine operation. To this end, Hobhouse pointed out that the solution to this problem: that is, if the countries must be given the most thoughtful consideration, then the individual should also be a corresponding work for the country. He also pointed out: With this mutual concern, with the awareness of citizens, law and conscience, between the Conflicts can be the reduction of confidence, in spite of their complete reconciliation it will always be a problem. Third, the freedom and force have a complementary function, and the autonomy of individual countries is not only a product of their own, but also the conditions of personal autonomy. From this we can easily find the freedom of Hobhouse is a kind of limitation of concept of freedom which advocates the harmonization between the countries.

At this point, we must point out that, if you read "On Liberty" at the same time and Mill's "Utilitarianism" ("Utilitarianism" 1963 edition) and "On representative government" ("On Representative Government", 1861 edition), do you have to harm beneficial?. Of course, if you are prepared in advance on Locke, Rousseau, Montesquieu, Paine and other scholars, you will have grasped the information on Jeremy Bentham, Gladstone, Richard Cobden and other materialists, and have known the combination of utopian and socialism on the relationship between freedom and authority "On the freedom of political and harmony" will be the solution which you are looking for.

At the history of the evolution of the Middle Ages, the Liberal theology seems to be a false picture of peace, but in the political writings of Thomas Aquinas it is still some complex theology as a cover for the pursuit of freedom. Aquinas in his "Encyclopedia of Theology" said: "The will is good, because it is the basis of human freedom." But when he discussed the relationship between freedom and authority, his freedom was a halo Theology of the shelter. He said, "to make use of free will be limitations, will be constrained by providence." It has become a secular society where the only authority, the state, individuals are submerged. Authority is the vast ocean of God. But we can never say it is a national nihilism .Aquinas believes that "Sometimes people will decide by foreign objects." here, "foreign objects" including secular countries, only at the Middle Ages in Europe he was not allowed to mention the environment which is higher than the national church, he was not allowed to even mention the name of the country, so he can only use "foreign objects" to depict the abstract which is need for the country.

Another theologian Augustine in his "City of God" has also pointed out: "It is God's free will on the knowledge of the fact that people will be free, that is, rather than the freedom of decision." This is a fact making the people to see the hearts of God's. Therefore inherent authority requires all people to obey God. He also believes that only in this way can we be free. Therefore, he said: "The freedom does not mean that there is no reason, it is just a result means." "We knew the result of "that is the hearts of God". In short, the medieval theologians who have been properly explored the issue of secular state as whole introduced the concept of political authority and Church authority. God is always in the duties and functions of the difference between the freedom and authority at the Middle Ages . The conflict and harmony completed in theology under the guise of evolution, this evolution of religion believed the religious authority, but it is, after all, never stopped.

Liberalism as a theory of systems, from Locke, Rousseau and Paine, who proposed systematically discussed "natural 
rights" theory. "Natural rights" theory is starting to prove freedom, equality and rationality of property ownership. Freedom and authority they discussed reflected the increased time and characteristics of the bourgeois concept of freedom. This reminds us of Rousseau's famous quote, "people naturally yearn for freedom, but everywhere he is in chains", but also reminds us hesitations Montesquieu discussed the relationship between freedom and legal authority: "Freedom is the law to do right thing." In short, it appears among the bourgeois of enlightenment thinkers, freedom is the longing for everyone, but freedom is relative, not absolute, world authority is not subject to any restrictions on freedom. Here, it mentioned Bentham's utilitarianism. Bentham's concept of freedom is different from the authority of the restrictions on freedom of Rousseau, and Bentham's utilitarian thinking is the core of his "greatest happiness principle", which clearly reflects the principle of laissez-faire doctrine of his color. This principle holds that happiness is an act of an institution or a social system and only the highest principles, "happy is better than painful pleasure ". Bentham even said that if people give the same happiness "will pushpin have the same meaning in poetry." Obviously, Benthamite utilitarianism has been pushed to the limits of liberalism, but also reflects the authority of Bentham tried to break through the fence of the desire and determination. But, as the authority does not preclude the freedom of individuality and the full development of the same individuals cannot be separated from the free development of the authority. Benthan's illusion of authority is precisely the hedonism and the awareness is always faced with the reality of the authority from the challenge. It is no wonder that American scholar Sabine indicated his nonsense indecent.

On Bentham, Mill has put forward a series of wishful slogans. From this, it is not difficult to see the spirit of the rational impulse of passion .Bentham and Cobden discussed the limitations of economic liberalism. This also shows that Mill's utilitarianism is different from egoism, hedonism. He believed that the interests of community are always above the personal interests. Everyone have no right to rule out the legitimate interests and display the rational principles. He talked about freedom and focused on social liberty rather than individual freedoms. Thus, he advocated social benefits are all good for people. Mill's liberalism ethics make him the new liberalist during the turn of $19^{\text {th }}$ century. It greatly influenced the later liberal thinkers.

When liberalism was prevalent in the British Isles, there were two European thinkers, they described the capitalist system into a merciless exposure. They start from the economic analysis of the entire superstructure of capitalism, pointing out that capitalism is bound to be replaced by the socialism. They pointedly noted: "the working class is not the means of production and consumption of information, they all have freedom. In a capitalist society, only freedom is the only value of the bourgeoisie, not for exploitation."Here, Marx and Engels pointed out that the interpretation of freedom is subordinated by the needs of political struggle; here, freedom is a means, is a tool, a weapon of struggle. From this we can see that under certain conditions free originated from outbreak of power. A taste of freedom to some extent is the issue of reverse passion. Marxist theory is not free to deny the premise of the authority, on the contrary, subject to making the freedom struggle. As Engels, "On the authority" pointed out, "The revolution is the most authoritative interpretation on history. With arms, bayonets, artillery, authority inclined to accept their will .If the bourgeoisie against the Paris city governance the authority will struggle for their surviving.

In theory, the Marxist concept of freedom is based on the recognition and awareness of the necessity to understand the necessity of the premise, and in such a default Marx pointed out: "Freedom is to understand and transform the inevitable," Here, Marx's exposition is bound to the same authority as the first condition. In short, Marxism in the relationship between freedom and authority apply not only to class conflict or social groups, but also to a more stable structure of the organization or entity.

Concept of freedom as a struggle for peace and freedom constitute the two main characteristics. In the former freedom is a means of propaganda, in the latter personality development and improvement is a typical view of peace and freedom. As Mill said: "In any era, just look at it a separate degree of freedom on how to apply the corresponding future generations ......Those who had damaged the human personality are authoritarian, either claiming to implement the will of God or claiming to be the implementation of the order." John Stuart Mill's "On Liberty "is not out of the entire freedom and the authority of dialectical unity between the barriers. The authors cited at the outset on the theory that: "to be discussed here is applied to the community beyond the legitimate power of the individual nature and limits." And pointed out that: "freedom and authority by far in our well-known part of history, especially in Greece, Rome and the history of the United Kingdom, The most significant characteristics has been developed to such independent authority in their own interest. With the other hand, they no longer think this is a natural need. "It is clear that Mill is a need to explore the new historical conditions of the individual and the national distribution of power. The authority of the state should be the extent to the protection of citizens or personal freedom? Mill pointed out, "In the part relating to himself, his independence is absolute. For my own, individual sovereignty is the highest. "

To this end, first of all, Mill defines the appropriate fields of human freedom. In this area include the following: First, the awareness within the state, the requirements of the broadest freedom of conscience; the requirements of the freedom of thoughts and feelings; asked whether it is in practice or a scientific or moral theology, such as subject all the views and sentiments of absolute freedom. Second, the fun and freedom of interests requires freedom to formulate their own 
plan of life; according to their own freedom to evade the consequences. Third, all individuals with this Freedom comes in the same limits, as well as the joint between the individual freedom.

Mill then pointed out that "in any society, if the freedom not being respected, the existence of freedom is not absolute and not subject to, it is not completely free." From this we can see that Mill's radical concept of bourgeois freedom.

In that case, the social role of the authority is limits of the individual, what is it? Mill pointed out: "Where the major part of personal life should belong to personality, where the main part of the community involved a matter of social life," " the behavior of any part of a harmful impact on the interests of others, the community has jurisdiction on the ... However, when a person's behavior does not affect their own interests, or unless they are willing to do not need to affect them, it does not contain the basis for any such problem. In all such matters, each person should have to implement the consequences of action and provide us with the legal and social freedom." Of course, even if a person's behavior is done in their own separate, it may indirectly affect other people, the relationship between freedom and authority is not consistent discussed.

Mill is not a laissez-faire, he is also contrary to the view that freedom has a limit. For example, if the prohibition of alcohol is harmful to them they can sought assurances. In limit production of the poison, he said: "If the poison is in addition to use, there is no other purpose, then the prohibition of the manufacture and sale of it is lawful. However, the needs of people can not only for the purpose of the innocent but for useful purpose, and the restrictions are not imposed on things that hinder this respect." Here, Mill made the state of interference problem, in the final analysis is still the relationship between freedom and authority issues.

On the public authority with personal liberty, the Mill has been made a vivid metaphor. He said that regardless of a public servant or any person, if we have known unsafe bridges, and too late to warn him of the danger, they can be recaptured, he is not considered as a real violation of his freedom; because a person is free to do what he do, and that this person does not want to fall in a river. However, sometimes a scourge of certainty has dangerous, with the exception of my own motives led him to taking the risk, I would like people (unless he was a child, or temporary nervous disorder, or is in the spirit of inappropriate excited state) should be warning, rather than should be scraped to prevent him from power. In the above-mentioned cases, Mill emphasized freedom of the degree of interaction and authority issues.

Mill put forward a proper standard of private life to interfere in the issue. He said: "individual and collective is able to interfere in private life, the sole purpose of self-protection is the individual must have the ability to mature. Children, mental patients and social degradation are not mature molecules, thereby does not apply to this standard." Western society has been discussing the issue of legislating private life, in fact, this issue was first raised by John Stuart Mill.

Mill extreme repress against the freedom of opinion and freedom of the press. In "On Liberty", a book he used a great deal of space to prove freedom of opinion and freedom of the press. He said: "suppression of opinion is bound to allow a dogma, that is, their own point of view has always been correct. However, if the views expressed by chance is correct, as long as the suppression of discussion, it is impossible to replace the error with the truth. On the other hand, if controversial views are wrong, and the suppression of discussion may be prejudiced by the error in the collision and has strong vitality get the truth." Government is not the best qualifications.

To sum up, Mill's liberalism has three characteristics: First, the recognition of political freedom and social freedom is a good thing, because freedom is a sense of social responsibility to create the real conditions of people. People living in accordance with their own way of life, develop their own innate characteristics and abilities, this is not a means of seeking happiness, but a substantial part of the well-being. Second, the freedom, not only the benefit of individuals, but also beneficial to society. Methods used to force a view to prevent publication, which is holding the kind of person who views the use of violence, but also deprived from the freedom of social research .In fact, individual rights is closely related to social and public interests. Third, in a free society, it not only makes it to be legislated civil liberties, and should be provided to enable more people to live closer to human conditions and less mandatory.

Of course, we should see the Mill as a thinker of the limitations of bourgeois. His theory is essentially free of the capitalist class service. At the same time, Mill's doctrine of freedom is also the limitations of the era or history, with the freedom of monopoly capitalism, the liberal idea of Mill has revealed its limitations. This has led to in 1880, the Oxford representative of the school (in the United States, Mill-Royce is to amend the doctrine of the most important representatives of the pragmatism). Green liberalism, its core idea is that he's on the personal and social relations of interdependence. In his view, the Government is dependent on the will, rather than relying on strong. Human society is subject to human nature itself, rather than legal punishment. For the establishment of the ideal of an open society is his most fundamental social impulse, which is also a moral impulse. The ideal requires moral equality, mutual respect, all people have the freedom to thought and action. Any member of the community must be the guiding moral responsibilities and constraints. Green believes that a moral society, the requirements of individual freedom should be based on the interests of the community, it is necessary to carry out self-restraint.

Green's re-interpretation of the liberal capitalism countries for future intervention provided an important 
implementation of the theoretical basis. From the perspective of social development, it adapted to the capitalist free market economy, which has a certain significance of historical progress. Modern liberalism has become more attractive during the transition period in 19 century.

\section{References}

Engels. On the authority. The Complete Works of Marx and Engels, Vol. 18, 341-344.

FN McGill. Treasure-house of world philosophy. Chinese Radio and Television Publishing House, No. 300, containing the original St. Augustine: City of God.

FN McGill. Treasure-house of world philosophy. Translated Editorial Board, China Radio and Television Publishing House, 701.

Hobhouse. (1996). Liberalism. the Commercial Press, 74-76.

Lanza John hober. Bein. (1980). History of Political Theory. Commercial Press, No. 795.

Mill. (1996). On Liberty. The Commercial Press.

Thomas Aquinas. Encyclopedia of Theology. The world's treasure house of Philosophy, p. 371. 